\title{
PERENCANAAN PENINGKATAN KEPUASAN MAHASISWA TERHADAP KUALITAS PELAYANAN PENDIDIKAN FAKULTAS TEKNIK INDUSTRI (STUDI KASUS PERGURUAN TINGGI SWASTA KOPERTIS WILAYAH 3 JAKARTA)
}

\author{
Rini Setiowati ${ }^{1}$ Hermanto $^{2}$, Nur Arifiya ${ }^{3}$ \\ Prodi Teknik Industri FTIK Universitas Indraprasta PGRI Jakarta \\ Rinisetiowati.unindra $\underline{80 @ g_{\text {gmail.com }}}$, $\underline{\text { hers } 3 \text { sm@gmail.com }}^{2}$, pipiya27@ gmail.com ${ }^{3}$
}

\begin{abstract}
A b s t r a k
"Perguruan Tinggi Swasta (PTS) ini merupakan salah satu perguruan tinggi swasta yang ada di Indonesia berdasarkan DIKTI Tahun 2015 PTS mendapat peringkat 125 dari 3320 Perguruan tinggi swasta di Indonesia Penelitian ini bertujuan untuk (1) Mengetahui faktor penyebab dari mahasiswa tidak puas terhadap pelayanan yang di terima dengan menggunakan metode Servqual di Fakultas Teknik Industri, (2) Menentukan upaya evaluasi perbaikan kualitas pelayanan dan kepuasan mahasiswa dengan menggunakan metode Importance-Performance Analysis (IPA) dan Quality Function Development (QFD) sebagai acuan penentuan prioritas tindakan perbaikan yang akan di lakukan oleh Universitas. Berdasarkan hasil yang diperoleh dengan menggunakan metode Servqual maka dapat diketahui bahwa tingkat kesenjangan (gap) antara kepuasan dan harapan mahasiswa terhadap kualitas jasa pendidikan saat ini di Fakultas Teknik Industri (FTI) Perguruan Tinggi Swasta (PTS) relative masih tinggi. Hal ini dapat dilihat dari semua indicator atau atribut layanan memiliki nilai negatif, yang berarti bahwa layanan jasa pendidikan yang diberikan oleh FTI PTS saat ini belum sesuai dengan harapan mahasiswa. Berdasarkan hasil yang diperoleh dengan menggunakan metode Importance Performance Analysis (IPA) maka dapat diketahui bahwa tingkat kinerja FTI PTS dan tingkat kepentingan mahasiswa saat ini cukup baik dan sangat tinggi. Hal ini terlihat dari cukup banyaknya atribut yang masuk pada kuadran II, yaitu sebanyak 23 atribut dari 37 atribut yang merupakan jumlah keseluruhan. Tingkat kinerja FTI PTS juga dapat dilihat dari tingkat kepuasan mahasiswa sementara tingkat kepentingan mahasiswa terlihat dari tingkat harapan mahasiswa. Berdasarkan hasil pengukuran terlihat bahwa rata-rata secara "Memuaskan" dengan nilai sebesar 78.38\% sedangkan rata-rata secara keseluruhan tingkat harapan mahasiswa FTI PTS berada pada kategori "sangat Penting" dengan nilai sebesar $78.38 \%$. Hasil temuan utama maka dapat dilakukan upaya-upaya perbaikan. Berikut usulan perbaikan berdasarkan prioritas utama secara urutan, yaitu : (1) Penggunaan internet menjadi ada, (2) Penginputan nilai mata kuliah $\leq 2$ minggu setelah berakhirnya ujian, (3) Kemampuan staf menanggapi keluhan mahhasiswa secara cepat, (4) Dukungan Sistem Informasi Akademik (SIA), (5) Kemampuan staf menyelesaikan complain paling lambat 3 hari, (6) Ketersediaan area parkir yang luas, (7) Kemampuan security mengatur kendaraan di area parkir, (8) Ketersediaan area kantin yang memadai, dan (9) Ketersediaan tempat foto copy.
\end{abstract}

Kata Kunci : Kualitas, Pelayanan, Servqual, Importance-Performance Analysis (IPA), Quality Function Development (QFD).

\section{PENDAHULUAN}

Perkembangan perusahaan saat ini bergerak secara dinamis baik dari segi kuantitas dan kualitasnya. Motto dari berbagai banyak perusahaan yang menyatakan bahwa tujuan perusahaan adalah untuk memuaskan pelanggan. Situasi ini hampir terjadi pada semua sektor baik pemerintah maupun swasta. Kini semakin disadari bahwa pelayanan dan kepuasan pelanggan merupakan aspek vital dalam rangka bertahan bisnis dan memenangkan persaingan khususnya dalam bidang pemasaran. 
Era globalisasi saat ini kualitas layanan dipandang sebagai salah satu alat untuk mencapai keunggulan kompetitif, karena kualitas layanan merupakan salah satu faktor yang dapat memuaskan mahasiswa. Kepuasan mahasiswa akan tercapai apabila kualitas jasa yang diberikan sesuai kebutuhannya. Kualitas layanan merupakan tingkat keunggulan untuk memenuhi keinginan mahasiswa dengan terbukanya pasar bebas dan era globalisasi telah menuntut adanya perubahan paradigma lama dalam segala bidang, salah satunya adalah bidang pemasaran. Semakin tinggi nya tingkat persaingan di bisnis lokal maupun global dan kondisi ketidakpastian memaksa perusahaan mencapai keunggulan bersaing agar mampu memenangkan persaingan di bisnis global.

Kualitas dimulai dari kebutuhan mahasiswa dan berakhir dari persepsi mahasiswa bukan dari persepsi perusahaan. Persepsi mahasiswa terhadap kualitas layanan merupakan penilaian total atas keunggulan suatu yang diberikan kepada mahasiswa. Layanan yang berkualitas memegang peranan yang sangat penting dalam fungsi pemasaran. Kualitas layanan yang baik merupakan satu hal yang sangat penting untuk memperoleh sesuatu yang kita inginan. Karena hal tersebut akan bermuara pada kepuasan.

Perguruan tinggi merupakan salah satu institusi yang bergerak di bidang pendidikan telah menunjukkan perkembangannya dari segi. Jumlahnya terus bertambah dari tahun ke tahun baik secara nasional. Kondisi ini menyebabkan terjadinya persaingan antar perguruan tinggi dalam penyediaan layanan jasa pendidikan secara professional sehingga sesuai dengan kebutuhan pasar kerja.

Penelitian ini di desain sebagai penelitian deskriptif secara kuantitatif melalui kuisioner dan Kualitatif dengan mengidentifikasikan untuk mendapatkan gambaran kualitas layanan di PTS pada berbagai karakteristik yang diinginkan oleh mahasiswa, dan menghubungkannya dengan persyaratan teknis layanan untuk memperbaiki desain layanan yang diharapkan akan berdampak pada perbaikan kualitas layanan yag diterima oleh mahasiswa pada umumnya. Penelitian dilakukan dengan 2 tahap yaitu tahap pertama dengan pengambilan data melalui kuisioner dan tahap kedua dengan mendeskripsikan kualitas pelayanan mahasiswa.

\section{METODE PENELITIAN}

Servqual merupakan pemilihan skala yang ringkas namun memiliki tingkat kebenaran yang cukup tinggi dan dapat digunakan manajemen perusahaan agar lebih mengerti bagaimana persepsi pelanggan dan harapan pelanggan akan pelayanan yang diberikan. Konsep servqual digunakan untuk menghitung antara persepsi pelanggan terhadap jasa dan nilai ekpektasi atau harapan.

Tabel 1. Operasional variabel Sevqual

\begin{tabular}{|c|c|c|c|c|c|}
\hline Variabel & Dimensi & Indikator & $\begin{array}{l}\text { Jenis } \\
\text { Data }\end{array}$ & Sumber & $\begin{array}{c}\text { Teknik } \\
\text { Pengambilan } \\
\text { Data }\end{array}$ \\
\hline \multirow{6}{*}{ HOQ } & Assurance & $\begin{array}{c}\text { Layanan Internet } \\
\text { Wifi }\end{array}$ & Primer & Responden & $\begin{array}{c}\text { Kajian Data } \\
\text { Sekunder }\end{array}$ \\
\hline & Tangible & $\begin{array}{l}\text { Ketersediaan } \\
\text { fasilitas parkir }\end{array}$ & Primer & Responden & $\begin{array}{l}\text { Kajian Data } \\
\text { Sekunder }\end{array}$ \\
\hline & Reability & $\begin{array}{l}\text { Ketersediaan } \\
\text { kantin dan tempat } \\
\text { foto copy }\end{array}$ & Primer & Responden & $\begin{array}{l}\text { Kajian Data } \\
\text { Sekunder }\end{array}$ \\
\hline & Tangible & $\begin{array}{c}\text { Publikasi nilai } \\
\text { UTS/UAS dn UPM }\end{array}$ & Primer & Responden & $\begin{array}{l}\text { Kajian Data } \\
\text { Sekunder }\end{array}$ \\
\hline & \multirow[t]{2}{*}{ Empaty } & $\begin{array}{c}\text { Penyelesaian } \\
\text { complain }\end{array}$ & Primer & Responden & $\begin{array}{l}\text { Kajian Data } \\
\text { Sekunder }\end{array}$ \\
\hline & & $\begin{array}{l}\text { Respon terhadap } \\
\text { keluhan mahasiswa }\end{array}$ & Primer & Responden & $\begin{array}{l}\text { Kajian Data } \\
\text { Sekunder }\end{array}$ \\
\hline
\end{tabular}

Sumber: Data diolah, 2015

JIM, Vol. 4, No. 1, Januari 2019, pp.1-6 


\section{Teknik Analisis Data:}

Teknik yang digunakan adalah menyebarkan kuesioner yang berisikan pernyataan-pernyataan tentang kepuasan dan harapan mahasiswa serta saran perbaikan terhadap pelayanan jasa pendidikan di FTI PTS ke setiap ruang kelas yang telah ditentukan dengan pengawasan langsung oleh peneliti saat berlangsungnya pengisian. Teknik pengambilan data yang digunakan adalah Purposive sampling, yaitu pengambilan sampel berdasarkan kriteris tertentu.

$$
n=\frac{N}{1+N e 2}
$$

\section{Analisis Kesenjangan Kenyataan dan Harapan}

Parasuraman (1988) menyimpulkan dari hasil penelitiannya bahwa terdapat lima dimensi SERVQUAL (kualitas jasa) yaitu dimensi berwujud (tangible), keandalan (reliability), ketanggapan (responsiveness), jaminan (assurance), dan empati (emphaty). Menurut Tjiptono (2008) pemilihan SERVQUAL didasarkan pada banyak keunggulan yang dimiliki sehingga menjadi model yang sangat baik untuk mengukur kualitas layanan hingga saat ini. SERVQUAL akan mengukur skor kualitas layanan yang menggambarkan layanan baik atau buruk dengan menghitung nilai gap yang dirasakan mahasiswa dari tingkat harapan dan kenyataan dari tiap-tiap atribut kualitas pelayanan.

\section{Analisis Kesesuaian Kepuasan Mahasiswa}

Dalam penentuan kualitas pelayanan kampus dari sisi mahasiswa dilakukan dengan menghitung tingkat kepuasan mahasiswa terhadap kualitas pelayanan pendidikan. Pengukuran tingkat kepuasan terhadap kualitas pelayanan pendidikan dilakukan dengan melakukan perbandingan antara kenyataan atas layanan yang diterima dengan harapannya. Hal ini di nilai mencerminkan kualitas pelayanan kampus dalam bentuk persen kesesuaian.

$T_{k i}=\frac{X_{i}}{Y_{i}} \times 100 \%$

\section{Uji Beda Kenyataan dan Harapan}

Uji beda rata-rata dikenal juga dengan nama uji-t (t-test). Konsep dari uji beda rata- rata adalah membandingkan nilai rata-rata beserta selang kepercayaan tertentu (confidence interval) dari dua populasi. Prinsip pengujian dua rata-rata adalah melihat perbedaan variasi kedua kelompok data.

Dalam menggunakan uji-t ada beberapa syarat yang harus dipenuhi. Syarat atau asumsi utama yang harus dipenuhi dalam menggunakan uji-t adalah data harus berdistribusi normal. Jika data tidak berdistribusi normal, maka harus dilakukan transformasi data terlebih dahulu untuk menormalkan distribusinya.

\section{Importance Performance Analysis (IPA)}

Menurut Leebov (2003) dalam pembuatan Importance-Performance Matrix, pertama kita harus menentukan terlebih dahulu, atribut pelayanan apa yang dinilai penting bagi mahasiswa sebagai customer, kemudian mengukur atribut tersebut dalam pelaksanaan pelayanan pendidikan yang diberikan. Jadi di sini persepsi pelanggan akan kualitas pelayanan menjadi hal sangat penting. Konsep Importance-Performance Matrix sebenarnya berasal dari konsep SERVQUAL. Intinya, tingkat kepentingan pelanggan (customer expectation) diukur dalam kaitannya dengan apa yang seharusnya dikerjakan oleh perusahaan agar menghasilkan produk jasa yang berkualitas tinggi. 


\section{HASIL DAN PEMBAHASAN}

\section{Uji Coba Kuesioner Pendahuluan}

Uji coba kuesioner dilakukan dengan cara menyebarluaskan kuesioner kepada 40 responden dalam hal ini mahasiswa di Fakutas Teknik Industri (FTI) PTS

\section{Uji Validitas Instrumen}

Validitas Intrumen untuk Kuesioner tingkat kepuasan layanan (Persepsi) Hasil uji validitas instrument menyatakan bahwa item-item pernyataan pada kuesioner dianggap memberikan hasil yang baik terhadap masalah yang ingin diukur. Data dikatakan valid jika $r$ Hitung > r Tabel. Berikut hasil pengukuran 37 item pernyataan yang digunakan untuk mengukur variable tingkat harapan layanan dengan menggunakan taraf signifikan $\alpha=0,05$.

\section{Tingkat Kepuasan (Persepsi) Mahasiswa}

Hasil pengukuran tingkat kepuasan mahasiswa terhadap 37 pertanyaan yang disurvei seperti terlihat pada tabel menunjukkan bahwa terdapat 3 kategori kepuasan konsumen atas layanan jasa pendidikan di FTI PTS, yaitu memuaskan, cukup memuaskan, dan tidak memuaskan. Sebanyak $5.40 \%$ berada pada kategori memuaskan dan $16.21 \%$ berada pada kategori tidak memuaskan. Jadi kalau dilihat rata-rata secara keseluruhan dari 37 pernyataan yang menjadi indicator atau atribut pelayanan di FTI PTS menunjukkan bahwa tingkat kepuasan mahasiswa di semester ganjil 2015/2016 berada pada kategori cukup memuaskan. Tingkat kepuasan pada kategori ini tidaklah membuat FTI PTS cepat berpuas diri, tetapi sebaiknya FTI PTS meningkatkan pelayanan yang berada pada tingkat cukup memuaskan, memperbaiki pelayanan yang berada pada tingkat tidak memuaskan dan mempertahankan pada tingkat memuaskan bahkan kalau perlu ditingkatkan lagi agar berada pada tingkat sangat memuaskan sehingga kepuasan mahasiswanya pun turut meningkat apabila hal ini dilakukan, maka menjadi keuntungan tersendiri bagi FTI PTS sebab akan meningkatkan citra FTI PTS di hadapan mahasiswa.

\section{Tingkat Harapan (Ekspektasi) Mahasiswa}

Hasil pengukuran tingkat harapan mahasiswa terhadap 27 pertanyaan yang disurvei seperti pada table 4.7 menunjukkan bahwa sebanyak 2 kategori harapan mahasiswa atas layanan jasa pendidikan di FTI PTS yaitu Sangat Penting dan Penting. Sebanyak $78.38 \%$ berada pada kategori Sangat Penting dan $21.62 \%$ berada pada ketegori Penting, jadi kalau dilihat rata-rata secara keseluruhan dari 37 pernyataan yang menjadi indicator atribut pelayanan di FTI PTS menunjang.

\section{Gap Antara Tingkat Harapan dan Tingkat Kepuasan Mahasiswa}

Analisis gap dilakukan untuk melihat kesenjangan yang terjadi antara harapan dan kepuasan mahasiswa terhadap layanan jasa pendidikan di FTI PTS. Gap dengan nilai negative memiliki arti bahwa kepuasan layanan yang dirasakan oleh mahasiswa tidak sesuai bdengan haapannya. Gap dengan nilai mendekati angka nol memiliki arti bahwa kepuasan layanan yang dirasakan oleh mahasiswa hampir sesuai dengan harapannya. Sementara gap dengan nilai nol atau positif memiliki arti bahwa kepuasan layanan yang dirasakan oleh mahasiswa sudah sesuai atau bahkan melebihi harapannya. Kondisi ini merupakan cita-cita dan harapan yang ingin diraih oleh semua perusahaan penyedia jasa layanan.

\section{Upaya Evaluasi Perbaikan Kualitas Pelayanan Akademik}

\section{Importance Performance Analysis (IPA)}

Hubungan setiap indikator pad tingkat kepuasan dan harapan mahasiswa secara rinci dapat dijelaskan dengan menggunakann matriks IPA (digram kartesius). Hasil analisis ini dapat dijadikan dasar perencanaan prioritas utama perbaikan kulaitas layanan di FTI PTS. Pada matriks IPA, yang menjadi prioritas utama adalah indikator-indikator yang berada pada kuadran I bahwa ada 6 indikator yang berada pada kuadran I, yaitu (1) Layanan intrenet Wifi, (2) Kesediaan 
fasilitas parkir, (3) ketersediaan kantin \& tempat ft. copy, (4) Publikasi nilai UTS/UAS UPM tepat waktu, (5) Penyelesaian complain dan (6) Respon terhadap keluhan mahasiswa.

Keenam indikator tersebut disarankan untuk segera dilakukan langkah-langkah perbaikan karena memiliki tingkat kepentingan yang tinggi tetapi persepsi mahasiswa terhadap kinerja indicator ini masih rendah atau dianggap belum memuaskan. Untuk memperoleh rancangan perbaikannya maka dilakukan penyusunan House of Quality (HoQ).

\section{Keterbatasan dalam Penelitian dan Implikasi Bagi Peneliti Yang Akan Datang}

Keterbatasan dalam penelitian ini adalah tidak dilakukan proses Benchmarking sebab kesulitan didalam memperoleh responden yang secara obyektif menilai kualitas pelayanan pada institusi pendidikan yang berbeda. Responden yang diminta mengisi kuesioner ini hanya pada kelas Reguler (Pagi) sehingga tidak dapat mencerminkan kualitas pelayanan FTI PTS secara keseluruhan.

\section{DAFTAR PUSTAKA}

Leebov, W. (2003). The Health Care Manager's Guide to Continuous Quality

Parasuraman, A., Zeithaml, V., dan Berry, L. (1988). Servqual: A Multiple-Item Scale for Measuring Consumer Perceptions of Service Quality. Journal of Retailing, 64 (1), 157 $-162$.

Parasuraman, A., Zeithaml, V., dan Berry, L. (2008). Delivering Quality Service. Canada : The Free Press.

Parasuraman, A., Zeithaml, V., dan Berry, L. (1991). Refinement and Reassessment of the SERVQUAL Scale. Journal of Retailing, 67 (4), 75 -89.

Parasuraman, A., Zeithaml, V., dan Berry, L. (1996). A Conceptual Model of Service Quality and Its Implications for Future Research. Journal of Marketing, 49 (2), 241 - 260.

Tjiptono, F. (2012). Service Management: Mewujudkan Layanan Prima. Yogyakarta: Andi.

Tjiptono, F. (2008). Manajemen Jasa. Yogyakarta : Andi. 
